\title{
Analisis Keefektifan Google Classroom Dalam Pembelajaran Daring
}

\author{
Tri Hartatik ${ }^{a, 1}$, Djatmiko Hidajat a, ${ }^{\star}$, Annisa Prima Exacta a,3 \\ ${ }^{a}$ Pendidikan Matematika Universitas Veteran Bangun Nusantara, Sukoharjo, Jawa Tengah, Indonesia \\ 2 djatmikohidajat@gmail.com* \\ * Corresponding Author
}

Diterima 18 Maret 2021; Disetujui 25 Maret 2021; Diterbitkan 25 Maret 2021

\begin{abstract}
This study aims to determine the level of effectiveness google classroom in online learning. This research uses quantitative methods through a google form questionnaire and is followed by quantitative descriptive data analysis. The population of this study were students of class XII SMA Veteran 1 Sukoharjo with a sample of 23 students from class XII BB. Based on the research, the average value of student learning outcomes was 79.348 with the high category. There were 21 students who completed and there were 2 people who had not completed or did not meet the completeness score of 70 . The results of student responses after being distributed by the questionnaire via google form showed that the percentage value of student responses was $60.87 \%$ in the moderate category. Based on the results of research and discussion, the level of effectiveness of Google Classroom is quite effective for delivering material, delivering and collecting assignments.
\end{abstract}

KEYWORDS

Google Classroom

Online learning

This is an openaccess article under the CC-BY-SA license

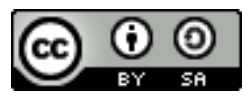

\section{Pendahuluan}

Generasi internet memerlukan penggerak mouse pada board atau hanya sentuhan screen komputer serta boleh masuk dan keluar dunia internet tanpa harus meninggalkan rumah. Generasi net lebih diekspresikan lagi kebebasannya kepada dunia sehingga mereka lebih merasa dianggap oleh dunia di sekitar mereka (Gunawan \& Sunarman, 2017). Salah satu cara yang dapat dilakukan dalam proses pembelajaran secara daring adalah dengan menggunakan google classroom. Pemanfaatan google classroom dapat melalui multiplatform yakni dengan menggunakan komputer dan dengan menggunakan android. Tujuan google classroom adalah memudahkan pembelajaran yang dapat direalisasikan dengan syarat kebermaknaan. Google classroom merupakan salah satu media belajar yang dapat membantu guru dalam mengelola pembelajaran dan menyampaikan informasi secara tepat dan akurat kepada siswanya (Wa Linda, 2020). Menurut Venkatesh dalam Kurniawati, et al. (2019), performance expectancy merupakan derajat dimana individu atau siswa mengharapkan bahwa dengan menggunakan sistem yang ada pada google classroom dapat membantu memperoleh keuntungan atau kemudahan dalam proses pembelajaran. Dengan melalui metode blended learning, maka peserta didik merasa nyaman dan aktif dalam mengkonstruksi pengetahuannya dalam pembelajaran. Berbagai fitur yang ada pada aplikasi google classroom dapat berguna bagi guru seperti assignments, grading, communication, timecost, archive course, mobile application, dan privacy dalam pembelajaran daring. Peneliti juga mengharapkan dapat memberi solusi terhadap metode yang selama ini diterapkan di kelas yaitu dengan metode konvensional dimana guru lebih mendominasi aktifitas pembelajaran baik dengan metode ceramah ataupun metode pemberian tugas.

Implementasi belajar mengajar dengan google classroom dapat mempermudah dalam mengevaluasi terlaksananya proses belajar mengajar baik di kelas maupun di luar kelas. Dapat mengkombinasikan pembelajaran antara metode konvensional dengan e-learning atau sering disebut Blanded Learning. Hal ini sejalan dengan penelitian Sjukur (2013) bahwa ada pengaruh hasil belajar siswa dengan motivasi belajar tinggi lebih baik dibandingkan dengan hasil belajar siswa dengan motivasi belajar rendah menggunakan model blended learning dengan media google classroom pada pembelajaran daring. Google classroom merupakan aplikasi dari google dengan tujuan untuk membantu guru dan peserta didik dalam proses belajar mengajar apabila kedua hal tersebut berhalangan, mengorganisasi kelas serta berkomunikasi dengan peserta didik tanpa harus terikat dengan jadwal pelajaran di kelas. Disamping itu guru dapat memberikan tugas dan langsung 
memberikan nilai kepada siswa. Penyampaian pembelajaran dengan e-learning adalah salah satu pembelajaran dengan pemanfaatan teknologi internet untuk meningkatkan lingkungan belajar dengan konten yang kaya dengan cakupan yang luas.

Google classroom merupakan sebuah aplikasi yang mungkin dapat menciptakan ruang kelas di dunia maya. Google classroom merupakan salah satu media pembelajaran dalam mendistribusikan tugas, submit tugas bahkan menilai tugas-tugas yang dikumpulkan (Naserly, 2020). Karena itu, aplikasi ini dapat berguna untuk membantu mempermudah guru dan siswa dalam melaksanakan proses belajar dengan lebih mendalam. Google classroom mempermudah siswa dan guru dalam mengumpulkan tugas, mendistribusikan tugas, menilai tugas di rumah atau dimanapun tanpa terikat batas waktu atau jam pelajaran saat pembelajaran daring berlangsung. Google classroom sebenarnya dirancang guna untuk mempermudah komunikasi guru dan siswa dalam dunia internet. Aplikasi ini menjadi kesempatan bagi guru untuk mengeksplorasi gagasan pengetahuan yang dimilikinya kepada siswa. Guru memliki waktu yang lebih panjang untuk mengajarkan kajian pengetahuan dan memberikan tugas mandiri kepada siswa, selain itu guru juga dapat membuat ruang kelas diskusi untuk siswa secara online. Ada beberapa syarat yang harus terpenuhi dalam mengaplikasikan google classroom yaitu membutuhkan jaringan akses internet yang cukup baik. Penggunaan aplikasi google classroom dapat dilakukan oleh siapa saja dan dimana saja tergabung dengan kelas tersebut. Kelas tersebut merupakan kelas yang didesain oleh guru sesuai dengan kelas sebenarnya atau kelas nyata di sekolah. Terkait dengan banyaknya anggota di dalam kelas dalam google classroom Iftakhar (2016) menjelaskan bahwa google classroom dapat digunakan bagi siapa saja dan dimana saja yang memiliki Google Apps for Education (GAFE), serangkaian media gratis termasuk gmail, dokumen, dan drive. Rancangan kelas yang digunakan dalam aplikasi google classroom sesungguhnya ramah lingkungan. Hal ini disebabkan siswa tidak menggunakan kertas dalam pengumpullan tuganya. Kurniawan, et al. (2020) menyatakan bahwa dalam kelas google classroom dirancang untuk membantu mempermudah guru dalam membuat dan mengumpulkan tugas tanpa media kertas, termasuk fitur yang menghemat waktu dan lebih efisien dibanding menggunakan media lainnya. Proses belajar mengajar berpusat pada peserta didik, para peserta didik adalah pengguna utama teknologi dan media internet terutama google classroom. Menurut Setyadi \& Qohar (2017) perubahan yang dialami oleh siswa antara lain adalah bertambahnya pengetahuan tentang teknologi yang semakin canggih, diperolehnya keterampilan atau kecekatan dalam mengerjakan tugas, dan berubahnya sikap seseorang yang telah belajar menggunakan google classroom. Pengetahuan dan pengalaman berasal dari pintu gerbang alat indra pembelajar (peserta didik). Media pembelajaran dapat menambah ketertarikan siswa karena tampilan materi yang menarik sehingga meningkatkan motivasi dan minat serta mengambil perhatian siswa untuk fokus mengikuti materi yang disajikan, sehingga guru mengharapkan efektivitas belajar akan meningkat pula.

Hanum (2013) menyimpulkan bahwa pembelajaran e-learning merupakan alat bantu pada pembelajaran di sekolah dasar-menengah yang memiliki persentase pembelajaran di sekolah antara teori dengan persentase yang lebih sedikit dibandingkan dengan praktek. E-learning bermanfaat untuk meningkatkan pemahaman materi, kemandirian dalam belajar dan memperluas wawasan sumber materi yang diajarkan maupun menambah aktivitas belajar serta membantu guru dalam mengefisiensikan waktu pembelajaran di dalam kelas google classroom. E-learning dapat bermanfaat dalam proses pembelajaran dan meningkatkan aktivitas belajar siswa, juga dapat bermanfaat sebagai media promosi sekolah di publik dan juga media pembelajaran yang dapat dimanfaatkan sebagai fasilitas pembelajaran online. Google Apps For Education (GAFE) sangat berpengaruh terhadap aktifitas siswa dalam pembelajaran daring, baik untuk interaksi pembelajaran daring, mengerjakan tugas-tugas, dan bahkan evaluasi terhadap proses pembelajaran daring. Dapat disimpulkan bahwa model pembelajaran daring berbasis e-learning dengan google classroom adalah teknik penyajian materi yang disajikan secara teratur berdasarkan pedoman yang terstruktur, yaitu: a) Mengidentifikasi media pembelajaran google classroom pada pembelajaran daring; dan b) Mengidentifikasi uji coba media yang telah dikembangkan pada penelitian selanjutnya, ujicoba dilaksanakan secara diperluas untuk diketahui kelayakan produk, praktis, efektif, dan efisien. Nurlayli, et al. (2021) menyatakan bahwa pembelajaran e-learning dapat membuat siswa lebih aktif.

Pembelajaran daring yang berbasis internet dapat dilakukan kapan saja dan dimana saja sesuai kesepakatan guru dan siswanya. Hal ini karena dirasa cukup sulit untuk dapat menerapkan protokol kesehatan di lingkungan sekolah sehingga pembelajaran daring merupakan salah satu alternatif yang cukup baik saat pandemi seperti saat ini. Pembelajaran daring merupakan salah satu alternatif proses 
belajar mengajar berbasis internet yang tidak mengharuskan siswa untuk hadir di sekolah. Selain itu, pembelajaran ini akan membentuk jiwa kemandirian belajar karena siswa diharuskan dapat menguasai materi sendiri di rumah, dan juga mendorong interaksi antar siswa, terutama untuk siswa yang biasanya tidak berani untuk mengungkapkan pendapatnya maka akan dapat lebih leluasa menyampaikan pendapat/pertanyaannya via tulisan jika dilakukan pembelajaran daring seperti saat ini. Sedangkan bagi guru, pembelajaran daring hadir dapat mengubah gaya mengajar konvensional yang mampu meningkatkan profesionalitas kerja dengan teknologi yang ada. Pembelajaran jarak jauh dengan menerapkan metode pemberian tugas secara online bagi para siswa melalui google classroom dipandang lebih efektif dalam kondisi darurat karena adanya virus corona seperti sekarang ini. Banyak guru yang mengimplementasikan dengan berbagai cara belajar dirumah, dari perbedaan belajar itu basisnya tetap pembelajaran secara daring tetapi tidak berada di lingkungan sekolah. Ada sebagian guru yang menggunakan konsep ceramah online, ada yang tetap mengajar di kelas seperti biasa tetapi divideokan kemudian dikirim ke grub kelas siswa dengan media google classroom, ada juga yang memanfaatkan konten-konten gratis dari berbagai sumber (Jamilah, 2020).

E-learning merupakan alternatif dalam proses pembelajaran yang menggunakan teknologi internet. Menurut Fitriasari, et al. (2020) pemanfaatan teknologi komputer dalam pembelajaran daring memberikan penguatan materi terhadap perubahan dalam proses pembelajaran saat ini. Sistem elearning adalah bentuk implementasi pembelajaran online berbasis internet yang memanfaatkan teknologi sehingga tidak dibatasi dengan ruang dan waktu yang dapat diakses kapan saja dan dimana saja. E-learning, disebut juga Tb-Learning (Technology-based Learning) adalah untuk mendukung belajar mengajar pada saat pembelajaran daring diperlukan aplikasi elektronik termasuk jaringan komputer (Internet, Intranet, Satelit), media elektronik (audio, tv, CD-ROM). Dalam e-learning pembelajaran dengan sistem ini dikenal dengan istilah LMS/CMS (Learning/Course Management System). Software LMS komersial yang populer diantaranya adalah WebCT, Blacckboard, TopClass, eCollege dan yang lainnya. LMS/CMS tidak saja menyediakan ruang dan waktu bagi guru dan siswa untuk mengakses materi pelajaran dan tugas-tugas tetapi juga menyediakan fasilitas lain seperti komunikasi langsung (chatting, teleconference, video conference), komunikasi tertunda (e-mail, mailing-list), pelacak progress (progress tracking), materi pelajaran (silabus, materi pelajaran, kumpulah soal-soal, latihan online) dan media lainnya.

E-learning adalah teknologi pembelajaran berbasis informasi yang relatif baru di indonesia. Elearning terdiri dari dua bagian yaitu 'e' singkatan dari 'elektronoc' dan 'learning' yang artinya 'pembelajaran'. Jadi e-learning berarti pembelajaran yang menggunakan perangkat elektronika, misalnya hanphone, android, tablet, laptop, komputer, dll. Google classroom adalah layanan media internet gratis, yang dikembangkan oleh Google, dengan tujuan untuk meminimalisir, membuat, mendistribusikan, dan menilai tugas tanpa harus bertatap muka antara guru dan siswa saat pandemi. Tujuan utama google classroom adalah agar dapat berbagi file antara guru dan siswa, seperti yang disampaikan oleh Wulantina (2019) penggunaan google classroom di sekolah dasar sampai sekolah menengah itu tanpa menyampingkan pembelajaran konvensional yang dilakukan seperti pada saat pembelajaran tatap muka. Google classroom atau ruang kelas google merupakan suatu sarana media pembelajaran campuran untuk ruang lingkup pendidikan yang dapat memudahkan pengajar dalam membuat, membagikan dan menggolongkan setiap penugasan tanpa kertas (paperless). Google classroom diperkenalkan sebagai salah satu keistimewaan media pembelajaran internet gratis dari Google Apps for Education (GAFE) (Graham \& Borgen, 2018). Menurut website resmi dari google, aplikasi google classroom merupakan media gratis yang meliputi email, dokumen dan penyimpanan pada google drive. Google classroom didesain untuk mempermudahkan guru dalam menghemat ruang dan waktu, mengelola kelas dan meningkatkan komunikasi dengan siswa-siswanya pada saat pandemi seperti ini. Dengan google classroom ini dapat mempermudahkan siswa dan guru untuk saling terhubung di dalam dan di luar sekolah tanpa harus tatap muka (Shaharanee, et al., 2016).

Seorang guru yang berasal dari New York, menyatakan bahwa ia selama 60 tahun mengajar tidak pernah sekalipun menggunakan komputer ataupun media elektronik lainnya. Namun, sejak memiliki Chromebook dan google classroom di dalamnya, dia bisa dengan mudah memberikan pekerjaan rumah digital kepada murid-muridnya dan memberikan tanggapan secara langsung, kapan pun dan di manapun (Al-Maroof \& Al-Emran, 2018). Google classroom didesain untuk beberapa pengguna antara lain yaitu guru, siswa, wali dan administrator. Manfaat bagi guru dapat mengelola kelas, tugas, nilai serta memberikan masukan secara langsung (real-time) pada media google classroom. Siswa 
dapat mengakses materi dan tugas kelas, berbagi materi dan berinteraksi dengan guru maupun teman dalam kelas google classroom atau melalui email, mengirim tugas dan mendapat masukan nilai secara langsung. Wali mendapat ringkasan email terkait tugas siswa. Administrator adalah seorang admin yang dapat membuat, melihat atau menghapus kelas di domainnya, menambahkan atau menghapus siswa dan guru dari kelas serta melihat tugas di semua kelas di domainnya (Apriana \& Hidajat, 2020). Pembelajaran berbasis e-learning yang digunakan pada penelitian ini adalah google classroom. Teknologi internet yang memiliki sifat interaktif, fleksible, dan tidak terbatas ruang dan waktu dan dapat dilakukan oleh siapa saja dan dimana saja adalah salah satu alternatif media pembelajaran yang unggul. Pemanfaatan teknologi sebagai media pembelajaran di kelas masih minim karena sebelumnya masih menggunakan aplikasi whatsApp. Untuk meningkatkan kualitas pembelajaran menjadi lebih baik, maka perlu diberikannya aplikasi pembelajaran yang mampu menumbuhkan semangat belajar dan ketertarikan siswa dari aplikasi yang digunakan khususnya e-learning dengan google classroom untuk mengoptimalkan proses pembelajaran Matematika di SMA Veteran 1 Sukoharjo. Implementasi dalam pembelajaran daring yang berbasis e-learning dengan google classroom sangat penting bagi guru dan siswa, maka penelitian ini bertujuan mengidentifikasi keefektifan pembelajaran berbasis google classroom, yaitu: a) Mengidentifikasi pengaruh penerapan google classroom pada proses belajar mengajar di kelas maupun diluar kelas pada saat pembelajaran daring; b) Mengetahui keefektifan perancangan dan pembuatan materi pembelajaran pada google classroom; c) Mengetahui keefektifan evaluasi pelaksanaan pembelajaran dengan google classroom; dan d) Mengidentifikasi respon siswa terhadap pembelajaran menggunakan google classroom yang diterapkan pada proses belajar mengajar.

\section{Metode}

Jenis penelitian yang digunakan adalah penelitian kuantitatif deskriptif. Penelitian ini digunakan untuk mendeskripsikan keefektifan pembelajaran google classroom pada pembelajaran daring. Desain penelitian yang digunakan adalah angket google form. Penelitian ini dilaksanakan mulai semester ganjil 2020/2021. Populasi dari penelitian ini adalah siswa kelas XII SMA Veteran 1 Sukoharjo. Penelitian ini mengambil sampel dari kelas XII BB SMA Veteran 1 Sukoharjo sebanyak 23 siswa. Instrumen yang akan digunakan dalam penelitian ini yaitu berupa tes hasil belajar siswa dan lembar angket keefektifan google classroom. Data dibutuhkan untuk memberikan informasi sesuai apa yang menjadi tujuan penelitian ini dengan cara sebagai berikut: 1) Metode dokumentasi dipakai untuk memperoleh data dokumen tentang jadwal pelajaran Matematika, daftar kelas XII BB semester ganjil tahun ajaran 2020/2021; 2) Metode tes digunakan untuk memperoleh data hasil belajar siswa kelas XII BB SMA Veteran 1 Sukoharjo. Tes yang diberikan pada siswa dalam penelitian ini berbentuk uraian sehingga dapat diketahui sejauh mana hasil belajar setelah mendapatkan pembelajaran Google Classroom; 3) Angket merupakan alat pengumpulan data melalui daftar pertanyaan atau pernyataan tertulis yang telah disusun oleh peneliti dan disebarkan kepada responden. Metode angket dalam penelitian ini bertujuan untuk mengidentifikasi tingkat keefektifan Google Classroom pada pembelajaran daring. Analisis data bertujuan untuk memberi makna terhadap data yang telah dikumpulkan. Hasil penelitian yang akan dianalisis secara deskriptif adalah data hasil belajar siswa dan data angket keefektifan Google Classroom dalam pembelajaran daring; dan 4) Data hasil belajar secara deskriptif ditunjukkan pada tabel distribusi frekuensi sehingga akan terlihat pencapaian siswa pada nilai-nilai tertentu. Kriteria yang digunakan untuk menentukan kategori hasil belajar siswa dalam penelitian ini merujuk kepada skala yang digunakan pada pembelajaran di SMA Veteran 1 Sukoharjo seperti pada Tabel 1 .

Tabel 1. Kriteria Hasil Belajar

\begin{tabular}{cc}
\hline Tingkat Penguasaan & Kategori \\
\hline $85-100$ & Sangat tinggi \\
\hline $70-84$ & Tinggi \\
\hline $56-69$ & Sedang \\
\hline $45-55$ & Rendah \\
\hline $0-44$ & Sangat rendah \\
\hline
\end{tabular}

Pendeskripsian hasil belajar siswa didasarkan pada tabel 2.1 diatas, dimana nilai telah mencapai ketuntasan belajar jika sudah diatas 70 . Skor hasil belajar akan dikategorikan dalam bentuk persentase ketuntasan belajar dengan rumus (1) 


$$
\mathrm{P}=\frac{f}{N} 100 \%
$$

dengan $\mathrm{P}$ adalah peserntase, $\mathrm{f}$ adalah frekuensi yang dicari persentase, dan $\mathrm{N}$ adalah jumlah subyek (sampel).

\section{Hasil dan Pembahasan}

Berdasarkan hasil penilaian tes hasil belajar siswa diperoleh bahwa skor tes hasil belajar siswa setelah diterapkan media pembelajaran google classroom cukup bervariasi. Adapun nilainya dapat dilihat pada tabel statistik tes hasil belajar siswa pada Tabel 2 .

Tabel 2. Statistik Tes Hasil Belajar Siswa

\begin{tabular}{cc}
\hline Statistik & Nilai Statistik \\
\hline Subjek & 23 \\
\hline Nilai Ideal & 100 \\
\hline Nilai Rata-rata & 79,348 \\
\hline Nilai Tertinggi & 100 \\
\hline Nilai Terendah & 0 \\
\hline Rentang Nilai & 100 \\
\hline Median & 85 \\
\hline Modus & 85 \\
\hline Standar Deviasi & 25,073 \\
\hline Variansi & 657,238 \\
\hline
\end{tabular}

Tabel di atas memberikan informasi bawa nilai rata-rata hasil belajar siswa pada mata pelajaran Matematika adalah sebesar 79,348 dengan standar deviasi 25,073. Nilai yang dicapai siswa adalah nilai tertinggi yang mungkin dicapai 100 dan nilai terendah yang mungkin dicapai 0 , dengan rentang nilai 100. Banyak siswa yang telah tuntas pada mata pelajaran Matematika ini sebanyak 21 orang (atau $91,304 \%$ tuntas) dan ada 2 orang yang belum tuntas atau belum memenuhi nilai ketuntasan 70 . Sementara, nilai rata-rata hasil belajar mahasiswa adalah 79,348 atau berada pada kategori tinggi.

Adapun hasil data yang diperoleh terkait dengan efektif dan efisiensi penggunaan google classroom dalam pembelajaran daring, dari 23 responden siswa yang diberikan angket hanya ada 14 siswa yang memberikan balikan. Dari data yang ada menunjukkan bahwa nilai persentase respon siswa adalah $60,87 \%$ atau berada pada kategori sedang. Hal ini dapat dikatakan bahwa penggunaan google classroom cukup efektif dan efisien sebagai pengganti pertemuan tatap muka. Adanya siswa yang tidak setuju mengungkapkan bahwa tidak $100 \%$ siswa setuju dengan penggunaan google classroom, dikarenakan banyak siswa yang terhalang karena sinyalnya tidak bagus. Sedangkan data dari soal tanggung jawab pengerjaan dan pengumpulan tugas melalui google classroom memberikan informasi bahwa siswa lebih bertanggung jawab dengan pengerjaan tugas dan pengumpulan tugas serta lebih tepat waktu dalam mengumpulkan tugas. Adanya siswa yang tidak setuju maupun yang sangat tidak setuju masih memberikan alasan yang sama bahwa sinyal di lingkungan mereka yang kurang mendukung untuk akses internet.

Berdasarkan data tabel diatas rata-rata nilai hasil belajar siswa XII BB di SMA Veteran 1 Sukoharjo pada mata pelajaran Matematika adalah 79,348. Sebanyak 21 siswa atau sekitar 91,304\% siswa dinyatakan tuntas dengan nilai akhir $\geq 70$ sedangkan sebanyak 2 siswa atau sekitar $8,696 \%$ siswa tidak dinyatakan tuntas karena memperoleh nilai akhir $<70$. Hasil observasi respon mahasiswa melalui pengumpulan data kuesioner diperoleh bahwa nilai prosentasenya sebesar $60,87 \%$. Hasil angket respons siswa, prosentase respons siswa (\%NRM) terendah adalah 78,13\% sedangkan prosentase respons siswa tertinggi adalah $92,5 \%$. Berdasarkan hasil observasi respon siswa terhadap penggunaan google classroom maka diperoleh data bahwa google classroom sangat berguna dalam proses pembelajaran Matematika. Hal ini dibuktikan dengan nilai prosentase respon siswa yang diperoleh sebesar $81,25 \%$, salah satunya siswa dapat melihat dan membuka materi maupun tugastugas yang sudah diupload pada google classroom.

Melihat analisis tersebut menunjukkan bahwa performa google classroom menunjang pembelajaran Matematika karena dengan google classroom memudahkan dalam menyimpan 
dokumen seperti materi maupun tugas penting yang di kirim lewat google classroom, jika siswa belum sempat untuk mencetak dokumen atau tugas yang dibutuhkan, mereka dapat mengakses terlebih dahulu melalui google classroomnya masing-masing. Selain itu siswa juga dipermudah untuk memperoleh pengumuman yang diberikan guru secara cepat (real time) sehingga menjadi efektif dan efisien dari segi waktu dan tempat. Siswa juga dapat melihat nilainya secara langsung setelah dikoreksi oleh guru mapel seperti yang terlihat pada Gambar 1 dan Gambar 2.

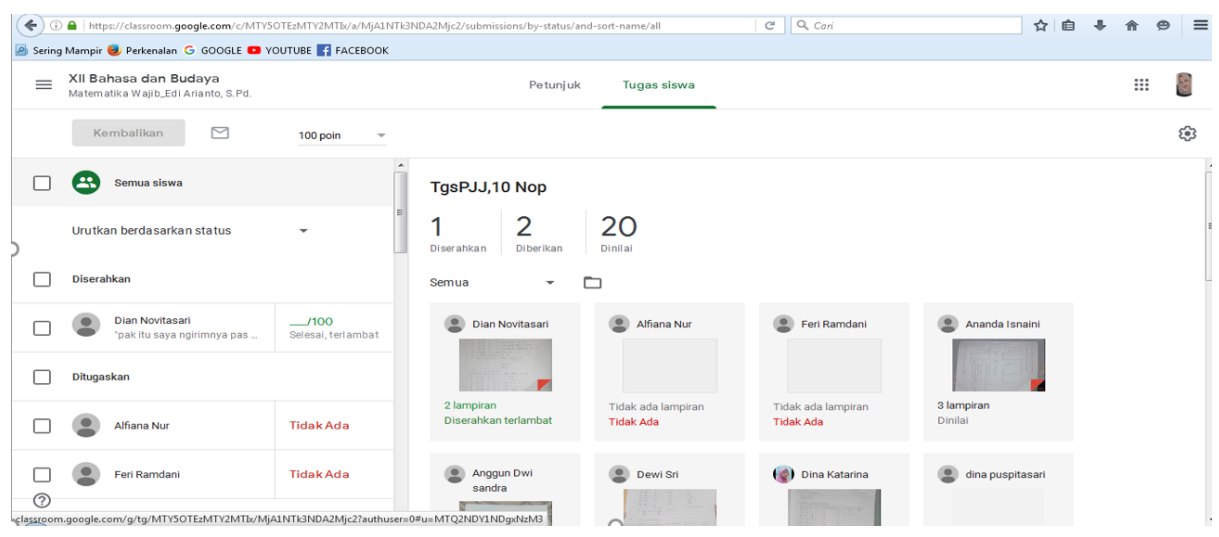

Gambar 1 Tampilan Penilaian Tugas di Google Classroom

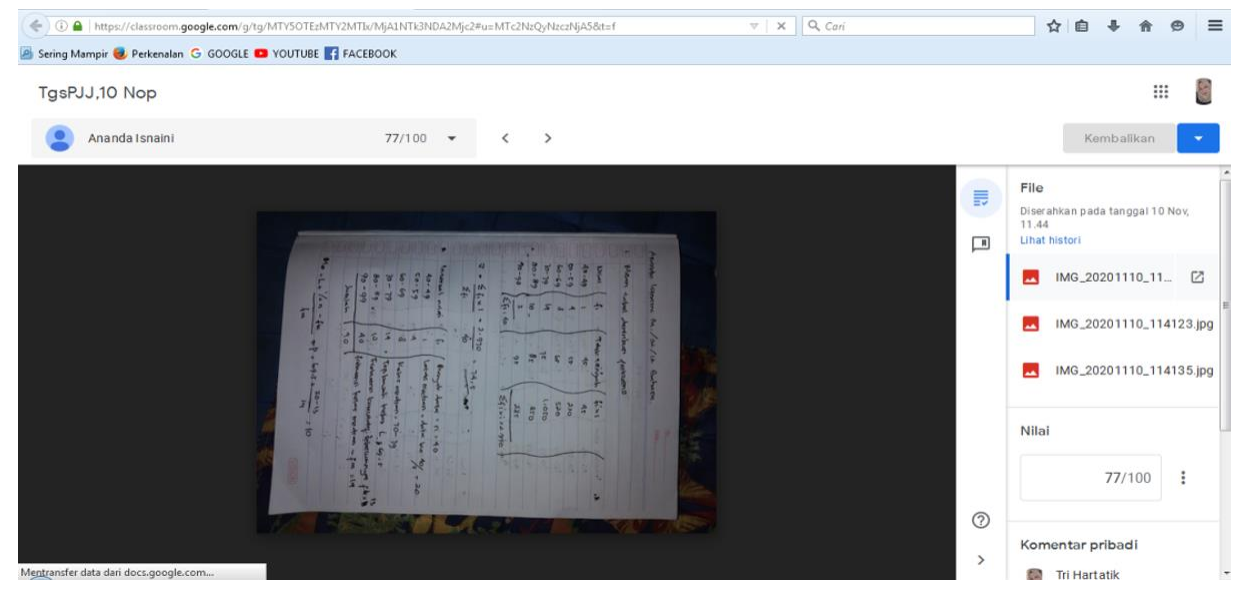

Gambar 2 Tampilan Tugas Indovidu Siswa di Google Classroom

Hal inilah yang membuat siswa termotivasi dalam pembelajaran karena tugas yang diberikan bisa setiap saat diperbaiki jika masih ada yang kurang, terlebih lagi mereka dapat mengetahui kapan deadline dari tugas yang diberikan. Selain itu, mereka tidak perlu menggunakan media kertas untuk mengumpulkan tugas-tugasnya cukup mengupload file ataupun gambar pada google classroom.

Dalam hal ini, diperoleh bahwa performa Google Classroom sebesar 78,75\%. Hal ini berarti siswa dalam melakukan proses pembelajaran Matematika yang dilakukan secara online lebih meningkatkan performa pembelajaran Matematika. Oleh karena itu, penggunaan Google Classroom dalam pembelajaran daring sangat efektif.

\section{Simpulan}

Berdasarkan hasil penelitian dan pembahasan di atas bahwa Google Classroom merupakan salah satu alternatif yang dapat digunakan sebagai media pembelajaran saat pandemi seperti ini. Tingkat keefektifan Google Classroom cukup efektif untuk penyampaian materi oleh guru dan pengumpulan tugas oleh siswa. Siswa lebih bertanggung jawab untuk mengerjakan dan mengumpulkan tugas, karena ada batasan waktu sesuai yang diberikan guru. Sedangkan untuk respon tanya jawab siswa melalui Google Classroom kurang efektif. Penggunaan Google Classroom pada pembelajaran Matematika ini agar siswa dapat mengenal, mengetahui dan memanfaatkan perkembangan teknologi 
di era yang modern. Karena sebelumnya siswa kelas XII BB SMA Veteran 1 Sukoharjo menggunakan aplikasi WhatsApp untuk pembelajaran.

Penggunaan Google Classroom dapat memudahkan guru untuk memberikan pengumuman, mengirimkan materi maupun tugas-tugas. Selain itu Google Classroom dapat memudahkan siswa untuk melihat pengumuman, mengelola tugas yang diberikan guru dan meninjau tugas sebelum dikirim. Tetapi selain banyak kelebihan Google Classroom juga mempunyai kekurangan yaitu, tampilan Google Classroom kurang menarik perhatian bagi siswa, jika Google Drive penuh tugas tidak dapat terkirim dan waktu pengumpulan tugas dapat diatur.

Penggunaan Google Classroom berdasarkan hasil penelitian dan pembahasan yang telah dikemukakan maka dapat disimpulkan bahwa media pembelajaran google classroom sangat efektif untuk mata pelajaran Matematika pada siswa kelas XII BB di SMA Veteran 1 Sukoharjo. Hal ini ditunjukkan dengan skor nilai rata-rata hasil belajar mahasiswa 79,348 yang berada pada kategori tinggi dan nilai persentase respon mahasiswa sebesar $60,87 \%$.

Berkaitan dengan penelitian ini peneliti dapat memberikan saran pada peneliti berikutnya bahwa perlu adanya penelitian pengembangan google classroom dalam dunia pembelajaran yang lebih luas agar dapat ditemukannya problematikan penggunaan google classroom sehingga dapat memberikan saran penyempurnaan.

\section{Referensi}

Al-Maroof, R. A. S., \& Al-Emran, M. (2018). Students acceptance of google classroom: An exploratory study using PLS-SEM approach. International Journal of Emerging Technologies in Learning. https://doi.org/10.3991/ijet.v13i06.8275

Apriana, A., \& Hidajat, D. (2020). Analysis of Google Classroom 's Online Learning Motivation on Mathematics Subjects. Journal of Mathematical Pedagpgy; ISSN 2715-7458; E-ISSN 27157466, 2(1), 18-25.

Fitriasari, N. S., Apriansyah, M. R., \& Antika, R. N. (2020). Pembelajaran Kolaboratif Berbasis Online. Inspiration: Jurnal Teknologi Informasi Dan Komunikasi. https://doi.org/10.35585/inspir.v10i1.2564

Graham, M. J., \& Borgen, J. (2018). Google Classroom. In Google Tools Meets Middle School. https://doi.org/10.4135/9781506360188.n3

Gunawan, F. I., \& Sunarman, S. G. (2017). Pengembangan Kelas Virtual dengan Google Classroom dalam Keterampilan Pemecahan Masalah (Problem Solving) Topik Vektor pada Siswa SMK untuk Mendukung Pembelajaran. Prosiding Seminar Nasional Etnomatnesia.

Hanum, N. S. (2013). Keefetifan E-learning sebagai Media Pembelajaran (Studi Evaluasi Model Pembelajaran E-learning SMK Telkom Sandhy Putra Purwokerto). Jurnal Pendidikan Vokasi. https://doi.org/10.21831/jpv.v3i1.1584

Iftakhar, S. (2016). Google Classroom: What Works and How? Journal of Education and Social Sciences.

Jamilah, M. (2020). Dampak Pembelajaran Daring di Tengah Pandemi COVID 19 pada Siswa Sekolah Dasar. Jurnal STKIP PGRI Sumenep.

Kurniawan, A., Prabowo, G., \& Falahudin, T. (2020). Media Pembelajaran Berbasis Google Classroom. Auto Tech: Jurnal Pendidikan Teknik Otomotif Universitas Muhammadiyah Purworejo. https://doi.org/10.37729/autotech.v15i2.528 
Kurniawati, M., Santanapurba, H., \& Kusumawati, E. (2019). Penerapan Blended Learning Menggunakan Model Flipped Classroom Berbantuan Google Classroom dalam Pembelajaran Matematika. EDU-MAT: Jurnal Pendidikan Matematika. https://doi.org/10.20527/edumat.v7i1.6827

Naserly, M. K. (2020). Implementasi Zoom, Google Classroom, dan Whatsapp Group dalam Mendukung Pembelajaran Daring (Online) pada Mata Kuliah Bahasa Inggris Lanjut. Journal of Chemical Information and Modeling.

Nurlayli, Hidajat, D., \& Primasari, E. (2021). Analisis Video Pembelajaran Daring dalam Permasalahan Sistem Persamaan Linear Tiga Variabel. Jurnal Gema Pendidikan; P-ISSN: 0854-9044; E-ISSN: 2684-866X, 28(1), 33-41.

Setyadi, D., \& Qohar, A. (2017). Pengembangan Media Pembelajaran Matematika Berbasis Web pada Materi Barisan dan Deret. Kreano, Jurnal Matematika Kreatif-Inovatif. https://doi.org/10.15294/kreano.v8i1.5964

Shaharanee, I. N. M., Jamil, J. M., \& Rodzi, S. S. M. (2016). Google Classroom As a Tool for Active Learning. AIP Conference Proceedings. https://doi.org/10.1063/1.4960909

Sjukur, S. B. (2013). Pengaruh Blended Learning terhadap Motivasi Belajar dan Hasil Belajar Siswa di Tingkat SMK. Jurnal Pendidikan Vokasi. https://doi.org/10.21831/jpv.v2i3.1043

Wa Linda. (2020). Efektivitas Penggunaan Google Classroom Sebagai Media Pembelajaran. Skripsi.

Wulantina, E., \& Sugama, M. (2019). Persepsi Peserta Didik terhadap Metode Blended Learning dengan Google Classroom. Jurnal Inovasi Matematika. https://doi.org/10.35438/inomatika.v1i2.156 